\title{
Two species of illegal South American sailfin catfish of the genus Pterygoplichthys well-established in Indonesia
}

Jiří Patoka ${ }^{1, *}$, Muhammad Takdir ${ }^{2}$, Yonvitner ${ }^{3}$, Hilman Aryadi ${ }^{4}$, Rikho Jerikho ${ }^{5}$, Jusri Nilawati ${ }^{6}$, Fadly Yasin Tantu ${ }^{6}$, Lucie Bohatá ${ }^{1}$, Asti Aulia ${ }^{2}$, Mohammad Mukhlis Kamal ${ }^{7}$, Yusli Wardiatno ${ }^{5,7}$ and Miloslav Petrtýl ${ }^{1}$

${ }^{1}$ Department of Zoology and Fisheries, Faculty of Agrobiology, Food and Natural Resources, Czech University of Life Sciences Prague, Kamýcká 129, 165 00, Praha-Suchdol, Czech Republic

2 Department of Fisheries, Faculty of Fisheries and Marine Sciences, University of Papua, Jalan Gunung Salju, 98314 Manokwari, Indonesia

${ }^{3}$ Department of Aquatic Resources Management, Faculty of Fisheries, Bogor Agricultural University and Centre for Disaster Studies (CERDAS-IPB), 16680 Bogor, Indonesia

${ }^{4}$ Program Studi Biologi, Faculty of Mathematics and Natural Science, Mataram University, Jalan Majapahit 62, 83115 Mataram, Indonesia

${ }^{5}$ Environmental Research Center, IPB University, Kampus IPB Dramaga, 16680 Bogor, Indonesia

${ }^{6}$ Department of Aquaculture, Faculty of Animal Husbandry and Fishery, Tadulako University, Jalan Soekarno-Hatta Km 9, Kampus UNTAD Tondo, 94118 Palu, Indonesia

${ }^{7}$ Department of Aquatic Resources Management, Faculty of Fisheries, IPB University, Kampus IPB Dramaga, 16680 Bogor, Indonesia

Received: 20 March 2020 / Accepted: 29 May 2020

Abstract - Sailfin catfish indigenous to South America are very popular ornamental fish, having previously been introduced to many regions outside their native range. Two species, namely Pterygoplichthys disjunctivus and P. pardalis, are illegal but widespread in Indonesia. They have formed self-sustaining populations, exploited for feeding of domestic animals and locally for human consumption. Also possible hybrids of the two mentioned species were recorded. The surveyed populations were considered established which perfectly fits with the climate matching analysis. Further monitoring and inspection of regions highlighted to be suitable for sailfin catfish is recommended.

Keywords: Pterygoplichthys pardalis / Pterygoplichthys disjunctivus / Loricariidae / biological invasion / climate matching / South-Eastern Asia / fish / aquarium trade

Résumé - Deux espèces de pléco sud-américains illégaux du genre Pterygoplichthys bien établies en Indonésie. Le pléco léopard voile, originaire d'Amérique du Sud, est un poisson d'ornement très populaire, ayant été introduit auparavant dans de nombreuses régions en dehors de son aire de répartition d'origine. Deux espèces, à savoir $P$. disjunctivus et $P$. pardalis, sont illégales mais très répandues en Indonésie. Elles ont formé des populations autonomes, exploitées pour l'alimentation des animaux domestiques et localement pour la consommation humaine. Des hybrides possibles des deux espèces mentionnées ont également été observés. Les populations étudiées ont été considérées comme établies, ce qui correspond parfaitement à l'analyse de la correspondance climatique. Il est recommandé de poursuivre la surveillance et l'inspection des régions jugées appropriées pour le pléco commun.

Mots-clés : Pterygoplichthys pardalis / Pterygoplichthys disjunctivus / Loricariidae / invasion biologique / adéquation climatique / Asie du Sud-Est / poisson / aquariophilie

\footnotetext{
*Corresponding author: patoka@af.czu.cz
} 
Non-native species are transported by humans both intraand intercontinentally for various purposes and related biological invasions cause biodiversity loss at both local and global scales (Lodge, 1993; Hulme, 2015; Pelicice et al., 2017; Vitule et al., 2019). Despite the activity of decisionmakers to mitigate risks of new introductions of identified high-risk species, the number of these events has a growing tendency and many regulations seem to be ineffective (Magalhães, 2015; Patoka et al., 2018). Moreover, intentional introductions ignoring the risk assessments, or based on a lack of data, still exist (Kumschick et al., 2016; Garcia et al., 2018).

South American sailfin suckermouth catfish species from the family Loricariidae such as Pterygoplichthys pardalis (Castelnau, 1855) and Pterygoplichthys disjunctivus (Weber, 1991) have expanded their native ranges to tropical, subtropical, and warm-water regions intercontinentally (e.g. Wakida-Kusunoki et al., 2007; Gibbs et al., 2008; Golani and Snovsky, 2013; Muralidharan et al., 2014; Samat et al., 2016). The number of introduction events and reports of newly established populations, counting also hybrids of both species, has a rising trend in recent years (Bijukumar et al., 2015; Orfinger and Goodding, 2018). Various biological and ecological characteristics such as parental care; large eggs that generate stronger juveniles to escape predators; nesting; extended spawning season; high fecundity; rapid growth; lifespan of more than five years; gulping air and extracting oxygen through the gut lining in low oxygen environments; armoured body; and ability to survive several hours of desiccation favour these catfish to be successful invaders (Hoover et al., 2004; Orfinger and Goodding, 2018). Even if not during the early era of modern ornamental aquaculture (Novák et al., 2020), currently, due to their characteristic attractive appearance, these fishes are very popular for ornamental fishkeeping (Maceda-Veiga et al., 2013). While most of the non-native populations originated from aquarium releases or escapes from fish hatcheries, evidence of introduction for other purposes such as human consumption cannot be excluded (Page and Robins, 2006; Golani and Snovsky, 2013; Sumanasinghe and Amarasinghe, 2014).

Once a new population is established, these species are very difficult to eradicate (Hill and Sowards, 2015; Orfinger and Goodding, 2018). Various negative impacts on native biota and habitats in invaded ranges are known: outcompeting of native species by altering food web dynamics (Page and Robins, 2006), inhabiting similar trophic niches (Meena et al., 2016), increases of turbidity, bank erosion and instability (Nico et al., 2009a), and disturbance during the foraging of manatees (Nico et al., 2009b).

Among socioeconomic negative impacts of sailfin catfish invasion, one can highlight damage to fishing gears by their spiny fins, dominance over the target exploited species in fish catches, and a subsequent decline in fishermen's livelihoods (Wakida-Kusunoki et al., 2007; Hubilla et al., 2008). Moreover, both mentioned species of sailfin catfish have been confirmed to serve as hosts for some parasites such as the dactylogyrid monogenean Heteropriapulus heterotylus, which can thus be introduced associated with the fish to new localities (Rodríguez-Santiago et al., 2016).

Previously, in Indonesia, $P$. pardalis was recorded in Java, Sulawesi and Sumatra, and P. disjunctivus in Java (Kottelat et al., 1993; Page and Robins, 2006; Muchlisin, 2012) where sailfin catfish are called ikan sapu-sapu. These fish are partly exploited by humans but, at least in the case of $P$. pardalis, the sailfin catfish are able to adapt to the heavy-metals-polluted environment and thus use of their flesh as local food products as exists in Java is hazardous (Ernawati, 2014). Usually, sailfin catfish have only been recorded in small quantities in these publications, but information from local people, on the other hand, suggests that the abundance is much higher in many sites. Therefore, we decided to update the information on sailfin catfish occurrence in Indonesia, with an evaluation of the establishment of these fish there in relation to climate matching models.

The sailfin catfish were sampled in selected localities in Java, Sulawesi and Lombok islands from 20 April to 21 September 2019, within the dry period. Fish were captured by angling in Java, with use of gill nets in Sulawesi (mesh size $3.5-4.5 \mathrm{~cm})$, and with cast nets $(4 \mathrm{~m}$ in diameter, mesh size $1 \mathrm{~cm}$ ). Captured fish were euthanized and preserved for later identification in formalin. All fish were sampled by researchers from Indonesian universities and local people were interviewed regarding the exploitation of sailfin catfish.

Sailfin catfish were identified using colouration patterning on the ventral part of the body: $P$. pardalis has ventral pigmentation patterns of uncoalesced, dark spots on a light background, whereas $P$. disjunctivus shows a vermiculate (worm-like) pattern (Page and Robins, 2006; Hossain et al., 2018).

In Indonesia, import of both illegal $P$. disjunctivus and P. pardalis is banned by Regulation No. 41/PERMEN-KP/ 2014, updated as Law No. PERMENKP/41/2014 (Patoka et al., 2018). Where non-native species have been introduced to a new locality, climate conditions together with other stressors affect the probability of becoming established and subsequently behaving as an invader (Hellmann et al., 2008). To assess the suitability of Indonesia for illegal sailfin catfish establishment, climate matching was analysed based on temperature characteristics. This was modelled from a dataset of environmental layers and native occurrence records of $P$. disjunctivus and $P$. pardalis using the MaxEnt software (v.3.4.1; https://biodiversityinformatics.amnh.org/ open_source/maxent) in order to determine the species environmental adaptability in Indonesia. Available GPS coordinates of their native occurrence (Orfinger and Goodding, 2018) were obtained from the Global Biodiversity Information Facility (GBIF, https://www.gbif.org). Environmental layers were obtained from the WorldClim database (v.1.4; http:// www.worldclim.org; Hijmans et al., 2005) with a spatial resolution of 2.5 arcmins $\left(\sim 1 \mathrm{~km}^{2}\right)$ and were assembled in QGIS 3.8.2 Zanzibar (https://qgis.org/en/site/) to ASCII format for use with the MaxEnt algorithm (Phillips, 2005). MaxEnt is a maximum entropy model well suited for species distribution mapping (Phillips et al., 2006; Phillips and Dudík, 2008). The model describes a continuous probability surface of habitat suitability in the target area and is widely used for forecasting alien species distribution (Giovanelli et al., 2008; Patoka et al., 2019; Yonvitner et al., 2020). The final set of bioclimatic predictors comprised: Annual Mean Temperature (BIO1), Mean Diurnal Range (BIO2), Isothermality (BIO3), Temperature Seasonality (BIO4), Maximum Temperature of Warmest Month (BIO5), Minimum Temperature of Coldest Month (BIO6), Temperature Annual Range (BIO7), Mean 


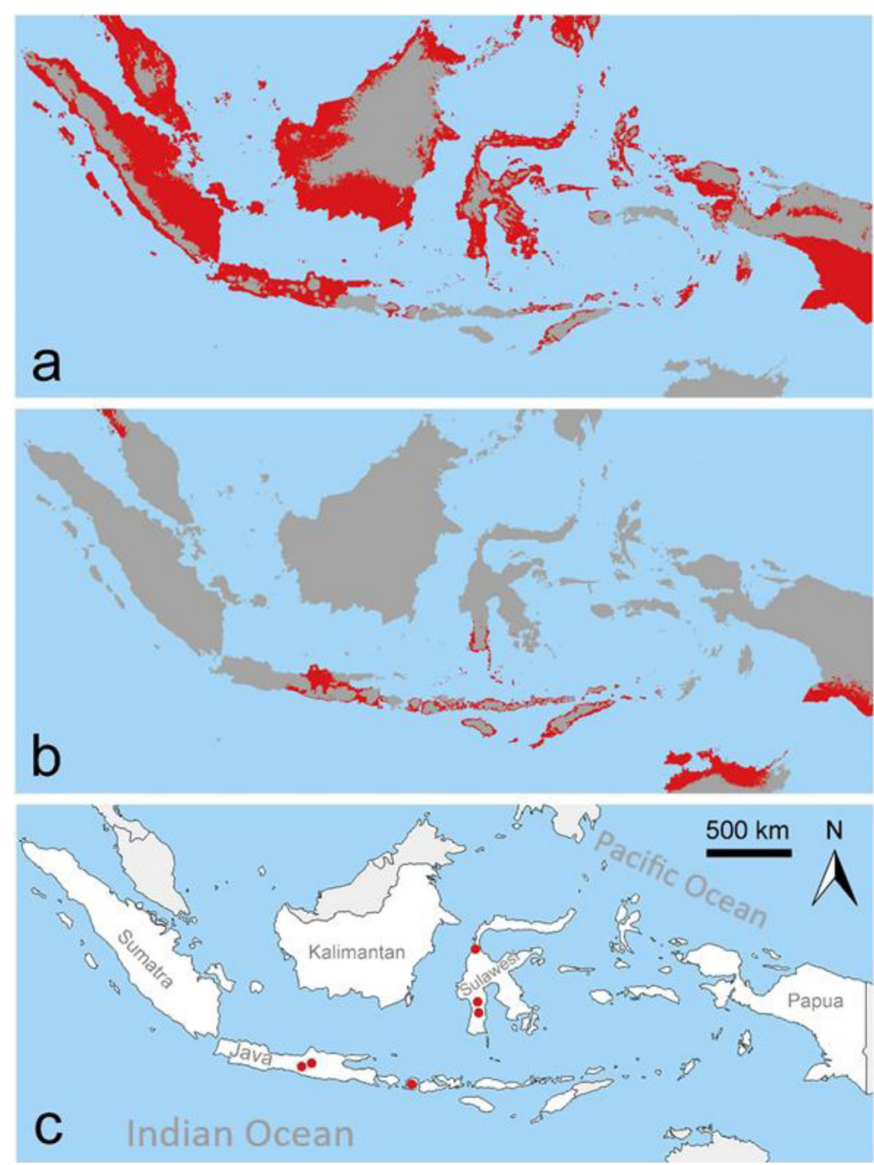

Fig. 1. Map of Indonesia, showing environmental suitability for Pterygoplichthys pardalis (a) and P. disjunctivus (b) computed by the MaxEnt model. Suitability shown in red colour represents the high probability of establishment. The localities with recorded occurrence of at least one of the mentioned species and/or their possible hybrids are indicated by red dots (c).

Temperature of Warmest Quarter (BIO10), and Mean Temperature of Coldest Quarter (BIO11). As a cumulative output, a continuous map was generated and visualised in QGIS 3.8.2 Zanzibar.

MaxEnt calculated a threshold value for $P$. disjunctivus $=$ 11.91 and for P. pardalis $=4.81$. If the value of the climate match reached or exceeded these thresholds, this was interpreted as no evidence of climatic constraints to the survival of the species and was shown in red on the map (Fig. 1). The value for the area under the receiver operator curve (AUC) was 0.995 for P. disjunctivus and 0.992 for P. pardalis, which means there was a $99 \%$ probability for both species that a random selection from presence records had a model score greater than a random selection from the absence records (Ward, 2007). Climate matching analysis showed a high probability especially for $P$. pardalis to become established in Indonesia when introduced to new localities (Fig. 1a), while P. disjunctivus had a much lower potential (Fig. 1b).

The found populations fit perfectly with the predicted suitable areas. Illegal sailfin catfish populations including numerous adults and juveniles were found well-established in the three Indonesian islands: Java, Lombok and Sulawesi (Fig. 1c, Tab. 1). In total, we captured 178 individuals of $P$. pardalis with an average body length of $248.7 \mathrm{~mm} \pm 75.4$ and average weight of $143.2 \mathrm{~g} \pm 140.0$, and 111 individuals of $P$. disjunctivus with an average body length of $245.9 \mathrm{~mm} \pm 59.3$ and average weight of $140.3 \mathrm{~g} \pm 140.7$. Also, 98 apparent hybrids were captured. The average body length of putative hybrids was $220.1 \mathrm{~mm} \pm 75.1$ and weight of $158.2 \mathrm{~g} \pm 153.1$. The biggest individual of $P$. pardalis had a body length of $532.0 \mathrm{~mm}$ and weight of $996.8 \mathrm{~g}$, compared to $470.0 \mathrm{~mm}$ and $950.0 \mathrm{~g}$ for the biggest individual of $P$. disjunctivus and $430.0 \mathrm{~mm}$ and $499.0 \mathrm{~g}$ for the biggest probable hybrid.

Captures of $P$. pardalis were made in all localities surveyed in Java and Sulawesi, and in seven localities in Lombok, while $P$. disjunctivus was captured at 11 localities, only in Lombok. Possible hybrids were captured in 10 localities just in Lombok (Tab. 1). Due to the differences in size in the found populations, characterizing juveniles and adults, and because all recorded populations were very abundant, we considered them as established and self-sustaining. No associated parasites or ectocommensals were recorded. Wu et al. (2011) suggested that a mixture of both mentioned species might help to increase their fitness during the invasion. Despite this assumption, we found apparent hybrids only in Lombok while the other populations in Java and Sulawesi seem to be well-established, and thus in good fitness, even if no hybrids were recorded there.

Based on the interviews, many local people catch fish including sailfin catfish in the dry season, with the use of cast nets and potassium toxins. The sailfin catfish are usually used as feed for ducks and chickens, but small quantities are exploited for human consumption. Even if we have no exact information about harvesting of sailfin catfish from the wild for the ornamental trade, this purpose cannot be excluded because Indonesia is one of the leading producers and exporters of ornamental aquatic creatures worldwide (Kalous et al., 2015; Patoka et al., 2015) and sailfin catfish are among popular aquarium fish species for these purposes.

Although previously mentioned mechanisms of introduction of illegal sailfin catfish in South Eastern Asia were releases from aquaria and escapes from aquaculture facilities (Page and Robins, 2006; Samat et al., 2016), we found one further pathway in Lombok: releasing of these fishes to mitigate another invasive pest, namely common water hyacinths (Eichhornia crassipes). Unfortunately, the sailfin catfish are bottom dwellers and water hyacinths are floating plants. Therefore, the purpose of the introduction was absolutely wrong and paradoxically caused the establishment of new invasive species in fresh waters in Lombok. Where both such species have been introduced by a combination of pathways or vectors, they can be defined as "polyvectic" sensu Carlton and Ruiz (2005).

Although the import of both sailfin species is banned by Indonesian laws (Patoka et al., 2018), the ban seems to be absolutely ineffective (i.e., a 'dead letter'), as both species were found to be well-established in Indonesia. Moreover, further species of sailfin catfish are traded as ornamentals, especially P. gibbiceps (Wu et al., 2011), and therefore, introduction of this species into the Indonesian wild can be expected in the near future if it has not already happened. 
Table 1. Recorded populations of Pterygoplichthys disjunctivus (Pd) P. pardalis (Pp) and mixture of both (H), island, locality name and GPS coordinates.

\begin{tabular}{llll}
\hline Species & Island & Locality & GPS coordinates \\
\hline $\mathrm{Pp}$ & Java & Majasto Canal & $7^{\circ} 42^{\prime} 15.732^{\prime \prime} \mathrm{S}, 110^{\circ} 46^{\prime} 32.646^{\prime \prime} \mathrm{E}$ \\
$\mathrm{Pp}$ & Java & Winongo River & $7^{\circ} 45^{\prime} 16.6104^{\prime \prime} \mathrm{S}, 110^{\circ} 21^{\prime} 27.594^{\prime \prime} \mathrm{E}$ \\
$\mathrm{Pd}, \mathrm{Pp}, \mathrm{H}$ & Lombok & Ancar River & $8^{\circ} 35^{\prime} 22.86^{\prime \prime} \mathrm{S}, 116^{\circ} 4^{\prime} 37.10^{\prime \prime} \mathrm{E}$ \\
$\mathrm{Pd}, \mathrm{Pp}, \mathrm{H}$ & Lombok & Babakan Rumak River & $8^{\circ} 38^{\prime} 27.11^{\prime \prime} \mathrm{S}, 116^{\circ} 7^{\prime} 39.34^{\prime \prime} \mathrm{E}$ \\
$\mathrm{Pd}, \mathrm{H}$ & Lombok & Batujai Dam & $8^{\circ} 44^{\prime} 8.80^{\prime \prime} \mathrm{S}, 116^{\circ} 15^{\prime} 26.65^{\prime \prime} \mathrm{E}$ \\
$\mathrm{Pd}, \mathrm{Pp}, \mathrm{H}$ & Lombok & Enyet Sepaket River & $8^{\circ} 35^{\prime} 23.4^{\prime \prime} \mathrm{S} 116^{\circ} 15^{\prime} 50.1^{\prime \prime} \mathrm{E}$ \\
$\mathrm{Pd}, \mathrm{Pp}$ & Lombok & Dodokan Gerung River & $8^{\circ} 41^{\prime} 27.3^{\prime \prime} \mathrm{S}, 116^{\circ} 06^{\prime} 35.1^{\prime \prime} \mathrm{E}$ \\
$\mathrm{H}$ & Lombok & Golong Narmada River & $8^{\circ} 35^{\prime} 35.4^{\prime \prime} \mathrm{S}, 116^{\circ} 12^{\prime} 36^{\prime \prime} \mathrm{E}$ \\
$\mathrm{Pd}, \mathrm{Pp}, \mathrm{H}$ & Lombok & Jangkok River & $8^{\circ} 34^{\prime} 23.58^{\prime \prime} \mathrm{S}, 116^{\circ} 4^{\prime} 41.70^{\prime \prime} \mathrm{E}$ \\
$\mathrm{Pp}, \mathrm{H}$ & Kermit River & $8^{\circ} 38^{\prime} 14.6^{\prime \prime} \mathrm{S}, 116^{\circ} 25^{\prime} 24.2^{\prime \prime} \mathrm{E}$ \\
$\mathrm{Pd}, \mathrm{H}$ & Lombok & Loang Balok River & $8^{\circ} 36^{\prime} 06.9^{\prime \prime} \mathrm{S}, 116^{\circ} 04^{\prime} 32.7^{\prime \prime} \mathrm{E}$ \\
$\mathrm{Pd}, \mathrm{Pp}, \mathrm{H}$ & Lombok & Meninting River & $8^{\circ} 32^{\prime} 54.78^{\prime \prime} \mathrm{S}, 116^{\circ} 6^{\prime} 39.51^{\prime \prime} \mathrm{E}$ \\
$\mathrm{Pd}$ & Lombok & Pandan Duri Dam & $8^{\circ} 41^{\prime} 15.77^{\prime \prime} \mathrm{S}, 116^{\circ} 26^{\prime} 18.29^{\prime \prime} \mathrm{E}$ \\
$\mathrm{Pd}, \mathrm{H}$ & Lombok & Pengga Dam & $8^{\circ} 45^{\prime} 30.07^{\prime \prime} \mathrm{S}, 116^{\circ} 11^{\prime} 43.71^{\prime \prime} \mathrm{E}$ \\
$\mathrm{Pd}$ & Lombok & Surabaya-Praya River & $8^{\circ} 42^{\prime} 47.25^{\prime \prime} \mathrm{S}, 116^{\circ} 17^{\prime} 7.27^{\prime \prime} \mathrm{E}$ \\
$\mathrm{Pp}$ & Lombok & Biromaru & $0^{\circ} 56^{\prime} 8.67^{\prime \prime} \mathrm{S} 119^{\circ} 54^{\prime} 6.41^{\prime \prime} \mathrm{E}$ \\
$\mathrm{Pp}$ & Sulawesi & Buaya Lake & $3^{\circ} 59^{\prime} 28.4^{\prime \prime} \mathrm{S} 120^{\circ} 00^{\prime} 48.2^{\prime \prime} \mathrm{E}$ \\
$\mathrm{Pp}$ & Sulawesi & Dolo, Biromaru & $0^{\circ} 53^{\prime} 0.95^{\prime \prime} \mathrm{S} 119^{\circ} 51^{\prime} 7.47^{\prime \prime} \mathrm{E}$ \\
\hline
\end{tabular}

Since very limited attention has been focused on invasive fish species in general and the illegal sailfin catfish in particular by both general public and government in Indonesia (Muchlisin, 2012; Patoka et al., 2018), we recommend presenting these findings to all stakeholders dealing with the sustainable exploitation and conservation of the rich biota in this region. Given that invasive species are able to survive extreme conditions, it is quite easy for the mentioned sailfin catfish of tropical origin to occupy and establish populations in water bodies with similar conditions as in Indonesia. Based on the climate matching maps, we suggest the further monitoring of those regions highlighted as suitable for sailfin catfish, to update our current knowledge about the occurrence and distribution of these species in Indonesia. Also, strong inspection of aquarium stores, ornamental fish farms, and fish importers is recommended because these species are illegal. In some localities, sailfin catfish were observed gulping atmospheric oxygen above the water level in polluted streams and this behaviour should be used for detection of the sailfin catfish in the wild without mandatory capture.

Acknowledgements. This study was supported by the institutional support RVO: 60460709. Rikho Jerikho acknowledges the project "Ichthys-Alien Indonesia". The English was proofread by Julian D. Reynolds.

\section{References}

Bijukumar A, Smrithy R, Sureshkumar U, George S. 2015. Invasion of South American suckermouth armoured catfishes Pterygoplichthys spp. (Loricariidae) in Kerala, India - a case study. J Threat Taxa 7: 6987-6995.

Carlton JT Ruiz G. 2005. Vector science and integrated vector management in bioinvasion ecology: conceptual frameworks.
In: Mooney HA, ed. Invasive Alien Species: a New Synthesis SCOPE 63. Washington, D.C.: Island Press, pp. 36-58.

Ernawati Y. 2014. The analysis of the concentration of heavy metals cadmium, mercury and lead in the flesh of suckermouth catfish (Pterygoplichthys pardalis) in Ciliwung River, Indonesia. Aquacult Aquar Conserv Legislat 7: 33-42.

Garcia DAZ, Magalhães ALB, Vitule JRS, Casimiro ACR, Lima-Junior DP, Cunico AM, Brito MFG, Petrere-Junior M, Agostinho ÂA, Orsi ML. 2018. The same old mistakes in aquaculture: the newly-available striped catfish Pangasianodon hypophthalmus is on its way to putting Brazilian freshwater ecosystems at risk. Biodivers Conserv 27: 3545-3558.

Gibbs M, Shields J, Lock D, Talmadge K, Farrell T. 2008. Reproduction in an invasive exotic catfish Pterygoplichthys disjunctivus in Volusia Blue Spring, Florida, USA. J Fish Biol 73: $1562-1572$.

Giovanelli JG, Haddad CF, Alexandrino J. 2008. Predicting the potential distribution of the alien invasive American bullfrog (Lithobates catesbeianus) in Brazil. Biol Invasions 10: 585-590.

Golani D, Snovsky G. 2013. Occurrence of suckermouth armored catfish (Siluriformes, Loricariidae, Pterygoplichthys) in inland waters of Israel. BioInvas Rec 2: 253-256.

Hellmann JJ, Byers JE, Bierwagen BG, Dukes JS. 2008. Five potential consequences of climate change for invasive species. Conserv Biol 22: 534-543.

Hijmans RJ, Cameron SE, Parra JL, Jones PG, Jarvis A. 2005. Very high resolution interpolated climate surfaces for global land areas. Int J Climatol 25: 1965-1978.

Hill JE, Sowards J. 2015. Successful eradication of the non-native loricariid catfish Pterygoplichthys disjunctivus from the Rainbow River, Florida. Manag Biol Invasion 6: 311-317.

Hoover JJ, Killgore KJ, Cofrancesco AF. 2004. Suckermouth catfishes: threats to aquatic ecosystems of the United States? Aquat Nuisance Spec Res Progr Bull 4: 1-14.

Hossain MY, Vadas RL Jr, Ruiz-Carus R, Galib SM. 2018. Amazon sailfin catfish Pterygoplichthys pardalis (Loricariidae) in 
Bangladesh: a critical review of its invasive threat to native and endemic aquatic species. Fishes 3: 14.

Hubilla M, Kis F, Primavera J. 2008. Janitor fish Pterygoplichthys disjunctivus in the Agusan Marsh: a threat to freshwater biodiversity. J Environ Sci Manag 10: 10-23.

Hulme PE. 2015. Invasion pathways at a crossroad: policy and research challenges for managing alien species introductions. $J$ Appl Ecol 52: 1418-1424.

Kalous L, Patoka J, Kopecký O. 2015. European hub for invaders: risk assessment of freshwater ornamental fish exported from the Czech Republic. Acta Ichthyol Piscat 45: 239-245.

Kottelat M, Whitten A, Kartikasari S, Wirjoatmodjo S. 1993. Freshwater Fishes of Western Indonesia and Sulawesi, Hong Kong.

Kumschick S, Devenish A, Kenis M, Rabitsch W, Richardson DM, Wilson JR. 2016. Intentionally introduced terrestrial invertebrates: patterns, risks, and options for management. Biol Invasions 18: $1077-1088$

Lodge DM. 1993. Biological invasions: lessons for ecology. Trends Ecol Evol 8: 133-137.

Maceda-Veiga A, Escribano-Alacid J, de Sostoa A, García-Berthou E. 2013. The aquarium trade as a potential source of fish introductions in southwestern Europe. Biol Invasions 15: 2707-2716.

Magalhães ALB. 2015. Presence of prohibited fishes in the Brazilian aquarium trade: effectiveness of laws, management options and future prospects. J Appl Ichthyol 31: 170-172.

Meena M, Sundaramanickam A, Kumar TTA. 2016. Occurrence of a Pterygoplichthys disjunctivus (Weber, 1991) population in Cauvery River System, Tamil Nadu, South India. Int J Fish Aquacult 8: 62-66.

Muchlisin Z. 2012. First report on introduced freshwater fishes in the waters of Aceh, Indonesia. Arch Polish Fish 20: 129-135.

Muralidharan M, Manikandan K, Gobi M. 2014. Extended distribution of the invasive Sucker catfish Pterygoplichthys pardalis (Pisces: Loricariidae) to Cauvery river system of Peninsular India. Int $J$ Aquat Biol 3: 14-18.

Nico L, Jelks H, Tuten T. 2009a. Non-native suckermouth armored catfishes in Florida: description of nest borrows and burrow colonies with assessment of shoreline conditions. Aquat Nuisance Spec Res Progr Bull 9: 1-30.

Nico LG, Loftus WL, Reid JP. 2009b. Interactions between nonnative armored suckermouth catfish (Loricariidae: Pterygoplichthys) and native Florida manatee (Trichechus manatus latirostris) in artesian springs. Aquat Inv 4: 511-519.

Novák J, Kalous L, Patoka J. 2020. Modern ornamental aquaculture in Europe: early history of freshwater fish imports. Rev Aquacult doi: 10.1111/raq.12421.

Orfinger AB, Goodding DD. 2018. The global invasion of the suckermouth armored catfish genus Pterygoplichthys (siluriformes: loricariidae): Annotated list of species, distributional summary, and assessment of impacts. Zool Stud 57: 2057-2007.
Page LM, Robins RH. 2006. Identification of sailfin catfishes (Teleostei: Loricariidae) in southeastern Asia. Raffles B Zool 54: 455-457.

Patoka J, Bohatá L, Karella T, Marková J, Yuliana E, Yonvitner Y. 2019. Invasive potential of pet-traded pill-box crabs from genus Limnopilos. Diversity 11: 91.

Patoka J, Kalous L, Kopecký O. 2015. Imports of ornamental crayfish: the first decade from the Czech Republic's perspective. Knowl Manag Aquat Ec 416: 4.

Patoka J, Magalhães ALB, Kouba A, Faulkes Z, Jerikho R, Vitule JRS. 2018. Invasive aquatic pets: failed policies increase risks of harmful invasions. Biodivers Conserv 27: 3037-3046.

Pelicice FM, Azevedo-Santos VM, Vitule JRS, Orsi ML, Lima-Junior DP, Magalhães ALB, Pompeu PS, Petrere M Jr, Agostinho AA. 2017. Neotropical freshwater fishes imperilled by unsustainable policies. Fish Fish 18: 1119-1133.

Phillips SJ. 2005. A brief tutorial on Maxent. AT\&T Research.

Phillips SJ, Anderson RP, Schapire RE. 2006. Maximum entropy modeling of species geographic distributions. Ecol Model 190: 231-259.

Phillips SJ, Dudík M. 2008. Modeling of species distributions with Maxent: new extensions and a comprehensive evaluation. Ecography 31: 161-175.

Rodríguez-Santiago MA, García-Prieto L, Mendoza-Garfias B, González-Solís D, Grano-Maldonado MI. 2016. Parasites of two coexisting invasive sailfin catfishes (Siluriformes: Loricariidae) in a tropical region of Mexico. Neotrop Ichtyol 14: e160021.

Samat A, Yusoff FM, Arshad A, Ghaffar MA, Nor SM, Magalhães ALB, Das SK. 2016. Reproductive biology of the introduced sailfin catfish Pterygoplichthys pardalis (Pisces: Loricariidae) in Peninsular Malaysia. Indian J Fish 63: 35-41.

Sumanasinghe H, Amarasinghe U. 2014. Population dynamics of accidentally introduced Amazon sailfin catfish, Pterygoplichthys pardalis (Siluriformes, Loricariidae) in Pologolla reservoir, Sri Lanka. Sri Lanka J Aquat Sci 18: 37-45.

Vitule JRS, Occhi TVT, Kang B, Matsuzaki SI, Bezerra LA, Daga VS, Faria L, Frehse FA, Walter F, Padial AA. 2019. Intra-country introductions unraveling global hotspots of alien fish species. Biodivers Conserv 28: 3037-3043.

Wakida-Kusunoki AT, Ruiz-Carus R, Amador-del-Angel E. 2007. Amazon sailfin catfish, Pterygoplichthys pardalis (Castelnau, 1855) (Loricariidae), another exotic species established in southeastern Mexico. Southwest Nat 52: 141-145.

Ward DF. 2007. Modelling the potential geographic distribution of invasive ant species in New Zealand. Biol Invas 9: 723-735.

Wu L-W, Liu C-C, Lin S-M. 2011. Identification of exotic sailfin catfish species (Pterygoplichthys, Loricariidae) in Taiwan based on morphology and mtDNA sequences. Zool Stud 50: 235-246.

Yonvitner Y, Patoka J, Yuliana E, Bohatá L, Tricarico E, Karella T, Kouba A, Reynolds JD. 2020. Enigmatic hotspot of crayfish diversity at risk: Invasive potential of non-indigenous crayfish if introduced to New Guinea. Aquat Conserv 30: 219-224.

Cite this article as: Patoka J, Takdir M, Yonvitner, Aryadi H, Jerikho R, Nilawati J, Tantu FY, Bohatá L, Aulia A, Kamal MM, Wardiatno Y, Petrtýl M. 2020. Two species of illegal South American sailfin catfish of the genus Pterygoplichthys well-established in Indonesia. Knowl. Manag. Aquat. Ecosyst., 421, 28. 